\title{
Mechanisms involved in calcium oxalate endocytosis by Madin-Darby canine kidney cells
}

A.H. Campos and N. Schor
Divisão de Nefrologia, Departamento de Medicina, Universidade Federal de São Paulo, São Paulo, SP, Brasil

\section{Correspondence \\ N. Schor \\ Rua Botucatu, 740 \\ 04023-900 São Paulo, SP \\ Brasil \\ Fax: + 55-11-573-9652 \\ E-mail: nschor.dmed@epm.br \\ Presented in part at the 30th Annual Meeting of the American Society of Nephrology, San Antonio, TX, USA, N ovember 1997. \\ Research supported by FAPESP, FOR and CNPq.}

Received February 25, 1999 Accepted October 13, 1999

\section{Abstract}

Calcium oxalate $(\mathrm{CaOx})$ crystals adhere to and are internalized by tubular renal cells and it seems that this interaction is related (positively or negatively) to the appearance of urinary calculi. The present study analyzes a series of mechanisms possibly involved in $\mathrm{CaOx}$ uptake by Madin-Darby canine kidney (MDCK) cells. CaOx crystals were added to MDCK cell cultures and endocytosis was evaluated by polarized light microscopy. This process was inhibited by an increase in intracellular calcium by means of ionomycin $(100 \mathrm{nM} ; \mathrm{N}=6 ; 43.9 \%$ inhibition; $\mathrm{P}<0.001)$ or thapsigargin $(1 \mu \mathrm{M} ; \mathrm{N}=6 ; 33.3 \%$ inhibition; $\mathrm{P}<0.005$ ) administration, and via blockade of cytoskeleton assembly by the addition of colchicine $(10 \mu \mathrm{M} ; \mathrm{N}=8 ; 46.1 \%$ inhibition; $\mathrm{P}<0.001)$ or cytochalasin $\mathrm{B}(10 \mu \mathrm{M} ; \mathrm{N}=8 ; 34.2 \%$ inhibition; $\mathrm{P}<0.001)$. Furthermore, $\mathrm{CaOx}$ uptake was reduced when the activity of protein kinase $\mathrm{C}$ was inhibited by staurosporine $(10 \mathrm{nM} ; \mathrm{N}=6 ; 44 \%$ inhibition; $\mathrm{P}<0.01)$, or that of cyclo-oxygenase by indomethacin $(3 \mu \mathrm{M} ; \mathrm{N}=$ $12 ; 17.2 \%$ inhibition; $\mathrm{P}<0.05)$; however, the uptake was unaffected by modulation of potassium channel activity with glibenclamide $(3 \mu \mathrm{M}$; $\mathrm{N}=6)$, tetraethylammonium $(1 \mathrm{mM} ; \mathrm{N}=6)$ or cromakalim $(1 \mu \mathrm{M} ; \mathrm{N}$ $=6$ ). Taken together, these data indicate that the process of $\mathrm{CaOx}$ internalization by renal tubular cells is similar to the endocytosis reported for other systems. These findings may be relevant to cellular phenomena involved in early stages of the formation of renal stones.
Key words

- Calcium oxalate

- MDCK cells

- Mechanisms of endocytosis

- Renal stone

\section{Introduction}

Calcium oxalate $(\mathrm{CaOx})$ crystals, the main constituent of urinary calculi, adhere in a specific manner to the plasma membrane of renal tubular epithelial cells in vitro and in vivo, and this process is rapidly followed by endocytosis. The tubular cells then exhibit a proliferative response, rearranging the cytoskeleton, increasing expression of "earlyimmediate" transcription genes (c-myc, cfos, nur-77), synthesizing fibrogenic sub- stances such as platelet-derived growth factor and connective tissue growth factor, and increasing absolute cell counts and viability (for a review, see Ref. 1).

There are controversies about the elements required for the development of urinary calculi. Although the exact role of the above mentioned phenomena has not been defined, recent experimental and clinical evidence points to the interaction between $\mathrm{CaOx}$ crystals and renal tubular epithelium as a factor involved in the genesis of urolithiasis. 
As observed in cell cultures, human kidney cells internalize crystals and proliferate when exposed to high concentrations of $\mathrm{CaOx}$ in vivo (e.g. primary hyperoxaluria, Crohn's disease-related malabsorption; 2,3). CaOxinduced excessive cell proliferation or damage (at higher concentrations) could lead to detachment of epithelial cells and basal membrane exposure. Epithelial denudation would permit a more intensive crystal adhesion $(4,5)$. Additional anchoring of $\mathrm{CaOx}$ particles would follow, allowing an expressive crystal nucleation and calculus growth (6). The traffic of particles through the basement membrane or even through intact tubular epithelium could also explain the presence of $\mathrm{CaOx}$ crystals in tubular interstitium. Considering the $\mathrm{CaOx}$ stimulus of proliferation, interstitial scarring sometimes seen in urolithiasis could also be a consequence of $\mathrm{CaOx}$ internalization by tubular cells.

Different substances have been described as modulators of adhesion and/or endocytosis processes. Nevertheless, despite the possible relevance of the $\mathrm{CaOx}$-tubular cell interaction, none of these drugs seems to be suitable for clinical use (1,7-12). The cellular pathways involved in endocytosis of $\mathrm{CaOx}$ crystals can constitute potential targets for drugs designed for the prophylaxis and/or treatment of urolithiasis. However, the mechanisms by which tubular cells take up $\mathrm{CaOx}$ need additional investigation.

The objective of the present study was to further clarify the cellular events related to this particular type of endocytosis employing Madin-Darby canine kidney (MDCK) cell culture.

\section{Material and Methods}

\section{Cell culture}

MDCK cells obtained from ATCC (American Type Culture Collection, Rockville, MD, USA) were cultured in Dulbecco's modified Eagle's medium (DMEM) supple- mented with fetal bovine serum (FBS; 5\%), $2 \mathrm{~g} / 1 \mathrm{NaHCO}_{3}, 2.6 \mathrm{~g} / 1$ HEPES, $10.000 \mathrm{IU} / 1$ penicillin, $50 \mathrm{mg} / \mathrm{l}$ streptomycin and 100 $\mathrm{mg} / \mathrm{l}$ neomycin. Cells were placed in polystyrene bottles at $37^{\circ} \mathrm{C}$ in a humidified gas mixture $\left(95 \%\right.$ air and $\left.5 \% \mathrm{CO}_{2}\right)$. Before each experiment cells were kept in DMEM without FBS for $24 \mathrm{~h}$ in order to obtain cells in the $\mathrm{G}_{0}$ phase of the cell cycle. At maximal confluence, cell treatments were performed and cell suspensions were obtained by exposure to trypsin-EDTA solution $(0.25 / 0.02 \%$, $\mathrm{w} / \mathrm{v}, 0.5 \mathrm{ml} /$ bottle). Cell viability was evaluated by the lactate dehydrogenase (LDH) assay (13) and confirmed by Trypan blue dye $(0.2 \%$; 5 to $15 \mathrm{~min})$ exclusion. Values higher than $90 \%$ in both methods were considered adequate.

\section{Preparation of calcium oxalate ( $\mathrm{CaO} \mathrm{x})$ crystals}

Equimolar solutions $(0.4 \mathrm{M}, 100 \mathrm{ml})$ of calcium chloride and potassium oxalate were combined and the mixture was added to distilled and deionized water (DDW, 300 $\mathrm{ml}$ ) by constant dripping for $2 \mathrm{~h}$. This suspension was maintained under continuous stirring at $75^{\circ} \mathrm{C}$ for $5 \mathrm{~h}$ and then washed with DDW to remove potassium chloride present in the supernatant. The remaining saturated solution was maintained at $37^{\circ} \mathrm{C}$ for 15 days until $\mathrm{CaOx}$ crystallization. $\mathrm{CaOx}$ crystals were then sterilized in ethylene oxide and culture medium without FBS was added, yielding a new suspension. In order to uniformize particle size, the suspension was sonicated for $12 \mathrm{~min}$. Qualitative analysis of $\mathrm{CaOx}$ was performed by X-ray diffractometry and crystal size was evaluated by laser chromatography with a CILAS 330 laser granulometer.

\section{MDCK cell exposure to $\mathrm{CaO} x$}

Confluent cell cultures were washed twice with PBS and exposed to the $\mathrm{CaOx}$ suspen- 
sion $(200 \mu \mathrm{g} / \mathrm{ml})$ for different periods of time (2, 6 and $24 \mathrm{~h})$. Cultures were then washed again in PBS and trypsinized. These procedures yield only cells containing internalized or strongly adhered crystals. Cell suspensions were analyzed by polarized light microscopy and $\mathrm{CaOx}$ crystal endocytosis was scored arbitrarily on a 0 to 4 scale, according to a previous report (14), as follows: 0 for cells without intracellular $\mathrm{CaOx}$ crystals, 1 for cells containing a single small $\mathrm{CaOx}$ crystal, 2 for cells with less than $50 \%$ of the cytoplasm area occupied by $\mathrm{CaOx}$ crystals, 3 for cells with 50 to $75 \%$ of the cytoplasm area filled with $\mathrm{CaOx}$ crystals, and 4 for cells with more than $75 \%$ of the cytoplasm area occupied by $\mathrm{CaOx}$ crystals. At least 100 cells per sample were counted and the final score was calculated according to the equation: (score 0 cells $\mathrm{x}$ ) $)+($ score 1 cells $\times 1)+($ score 2 cells $\times 2)+($ score 3 cells x 3$)+($ score 4 cells $x 4)$ /total number of cells. In another set of experiments, after determination of the best incubation period, cells were exposed to different concentrations of $\mathrm{CaOx}(10,50,100,200$ and $300 \mu \mathrm{g} /$ $\mathrm{ml}$ ) for $6 \mathrm{~h}$ and the $\mathrm{CaOx}$ cell uptake was evaluated. The intracellular position of $\mathrm{CaOx}$ crystals was confirmed in some representative cell cultures at different incubation times by laser scanning confocal microscopy (BioRad 1024-UV confocal system coupled to a microscope Zeiss Axiovert 100, BioRad, Hercules, CA, USA).

\section{Effect of different drugs on $\mathrm{CaO} x$ crystal endocytosis}

MDCK cells were exposed to $\mathrm{CaOx}(200$ $\mu \mathrm{g} / \mathrm{ml}, 6 \mathrm{~h}$ ) in the absence (vehicle only) or in the presence of each of the following drugs, added to the medium at submaximal concentrations 30 min before $\mathrm{CaOx}$ administration: $10 \mathrm{nM}$ staurosporine (a protein kinase $\mathrm{C}$ inhibitor), $3 \mu \mathrm{M}$ indomethacin (a cyclo-oxygenase inhibitor), $3 \mu \mathrm{M}$ glibenclamide (an ATP-sensitive potassium channel blocker), $1 \mathrm{mM}$ tetraethylammonium (a nonspecific potassium channel blocker), $1 \mu \mathrm{M}$ cromakalim (an ATP-sensitive potassium channel opener), $100 \mathrm{nM}$ ionomycin (a calcium ionophore), $1 \mu \mathrm{M}$ thapsigargin (an endoplasmic reticulum calcium ATPase inhibitor), $10 \mathrm{nM}$ nifedipine (a voltage-dependent calcium channel blocker), $10 \mu \mathrm{M}$ colchicine (a microtubule assembly inhibitor) or $10 \mu \mathrm{M}$ cytochalasin B (an actin microfilament assembly inhibitor). CaOx crystal uptake was then evaluated as described above.

\section{Statistical analysis}

Data related to $\mathrm{CaOx}$ endocytosis were reported as mean scores \pm standard error of the mean (SEM). When different groups were compared, data were presented as percent of control (absolute values in the text). Laser granulometry results were expressed as noncumulative frequency of distribution of crystal sizes in only one sample. After log transformation of raw data, experimental and control groups were compared by the unpaired Student $t$-test. P values of less than 0.05 were considered significant.

\section{Drugs and reagents}

PBS, DMEM, penicillin/streptomycin/ neomycin solution, Triton X-100, NADH, sodium pyruvate, Tris-HCl, Trypan blue, ionomycin, indomethacin, colchicine, nifedipine, thapsigargin, tetraethylammonium, cromakalim, cytochalasin B, and glibenclamide were purchased from Sigma Chemical Co. (St. Louis, MO, USA). Trypsin-EDTA solution and FBS were obtained from Sigma Chemical Co. or Cultilab (Campinas, SP, Brazil). Ethanol P.A., DMSO and all salts were purchased from Merck S.A. (Rio de Janeiro, RJ, Brazil). Staurosporine was supplied by Calbiochem-Novabiochem Co. (La Jolla, CA, USA). Glibenclamide, staurosporine and cytochalasin $\mathrm{B}$ were dissolved in DMSO. Ionomycin, indomethacin, nifedi- 
Figure 1 - A, Time-response internalization of calcium oxalate (CaOx) crystals $(200 \mu \mathrm{g} / \mathrm{ml})$ by MDCK cells. $* \mathrm{P}<0.001 \mathrm{com}$ pared to 6 and $24 \mathrm{~h}$ (Student ttest). B, Concentration-response curve for $\mathrm{CaOx}$ crystal internalization by MDCK cells after a 6-h exposure period. C, Viability of MDCK cells with (closed column) or without (open column) $\mathrm{CaOx}$ exposure for $6 \mathrm{~h}$ expressed as percentage of intraand extracellular lactate dehydrogenase (LDH) activity. The columns represent the mean and the bars the SEM of at least 6 experiments. pine and cromakalim were dissolved in ethanol. The remaining substances were dissolved in DDW or $0.9 \% \mathrm{NaCl}$. The final concentrations of ethanol or DMSO in the culture medium never exceeded $0.01 \%$. We assured that these substances had no detectable ef-
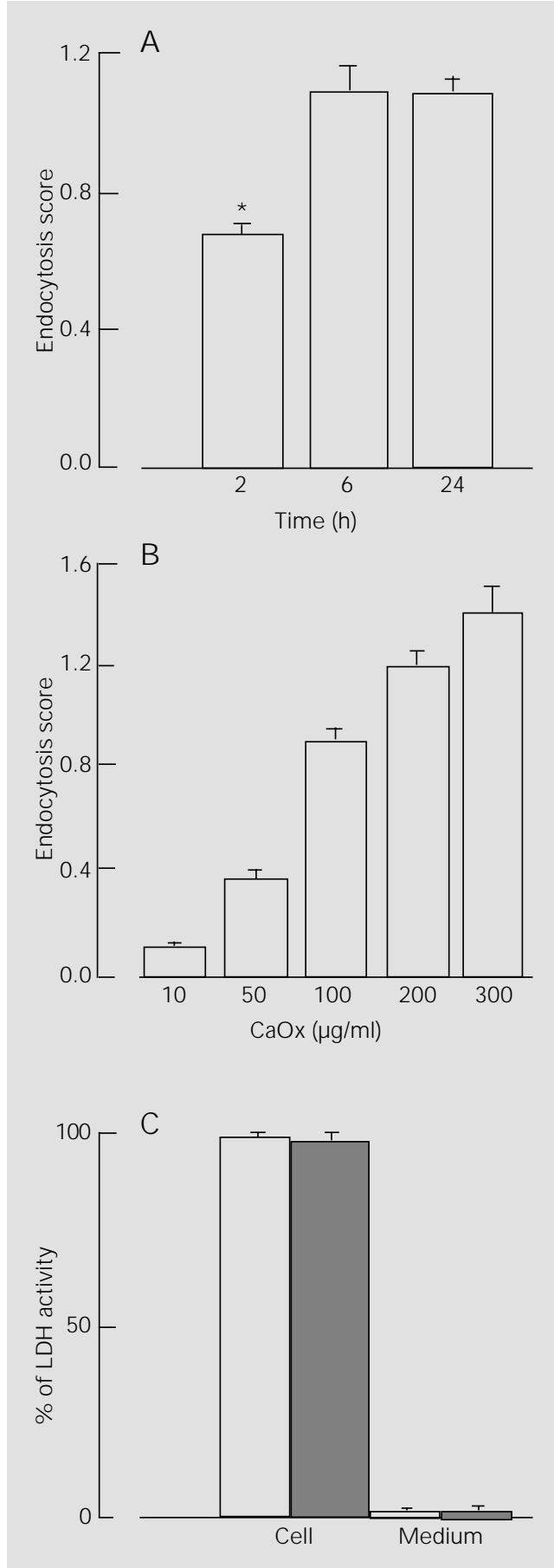

fect on cell viability or $\mathrm{CaOx}$ endocytosis process.

\section{Results}

\section{Physical characteristics of $\mathrm{CaO}$ x crystals}

$\mathrm{CaOx}$ sample analysis by X-ray diffractometry yielded a purity grade higher than 95. The mean and median size of $\mathrm{CaOx}$ crystals in a single sample evaluated by laser granulometry was 3.94 and $4.99 \mu \mathrm{m}$, respectively (data not shown).

\section{Time- and concentration-dependent $\mathrm{CaOx}$ endocytosis}

MDCK cells internalized $\mathrm{CaOx}$ crystals in a time-dependent manner. As can be seen in Figure 1A, the score obtained after a 2-h exposure period was $0.67 \pm 0.04$, reaching $1.09 \pm 0.08$ at $6 \mathrm{~h}(\mathrm{~N}=6 ; \mathrm{P}<0.001)$. The magnitude of endocytosis did not change significantly after $24 \mathrm{~h}$ of incubation $(\mathrm{N}=6$; $\mathrm{P}=\mathrm{ns})$. At $6 \mathrm{~h}$, MDCK endocytosis exhibited a concentration-dependent pattern from 10 to $300 \mu \mathrm{g} / \mathrm{ml}(0.11 \pm 0.01$ to $1.43 \pm 0.11$; $\mathrm{N}=6-34)$ (Figure 1B). Although the concentration-response curve did not reach a plateau, higher $\mathrm{CaOx}$ concentrations were not employed due to cytotoxicity. Cell viability was not impaired by exposure to $\mathrm{CaOx}(200$ $\mu \mathrm{g} / \mathrm{ml}$ ) for $6 \mathrm{~h}$, with a mean intracellular LDH activity of $99.2 \pm 0.3 \%$ and $98.7 \pm$ $0.4 \%(\mathrm{~N}=6 ; \mathrm{P}=\mathrm{ns})$ for control and exposed cells, respectively (Figure 1C).

\section{Effect of different drugs on $\mathrm{CaO} x$ endocytosis}

As can be observed in Figure 2A, increasing $\left[\mathrm{Ca}^{2+}\right]_{\mathrm{i}}$ by means of endoplasmic reticulum $\mathrm{Ca}^{2+}$-ATPase blockade with thapsigargin significantly inhibited the endocytotic response of MDCK cells (33.3\% inhibition; $\mathrm{N}=6 ; \mathrm{P}<0.005)$. Similar results were obtained when $\left[\mathrm{Ca}^{2+}\right]_{\mathrm{i}}$ was enhanced by changing plasma membrane permeability to 
extracellular calcium with ionomycin $(43.9 \%$ inhibition; $\mathrm{N}=6 ; \mathrm{P}<0.001)$. On the other hand, the inhibition of voltage-dependent calcium channels by nifedipine did not promote alterations in cellular $\mathrm{CaOx}$ uptake $(\mathrm{N}$ $=6 ; \mathrm{P}=\mathrm{ns})$ (Figure 2A). The absolute scores of the control groups compared to the thapsigargin, ionomycin and nifedipine groups were $1.32 \pm 0.10,1.27 \pm 0.06$ and $1.22 \pm 0.06(\mathrm{~N}$ $=6$ ), respectively.

Staurosporine markedly reduced $(44 \%$ of control; $\mathrm{N}=6 ; \mathrm{P}<0.01)$ the uptake of $\mathrm{CaOx}$ crystals after an exposure time of $6 \mathrm{~h}$ (Figure 2B). On the other hand, indomethacin had only a discrete, although statistically significant, inhibitory effect on $\mathrm{CaOx}$ endocytosis (17.2\% of control; $\mathrm{N}=12 ; \mathrm{P}<0.05$ ) (Figure 2B). The scores obtained for the control groups were $1.32 \pm 0.10(\mathrm{~N}=6)$ and $1.22 \pm 0.03(\mathrm{~N}=12)$ for staurosporine and indomethacin, respectively.

According to the data in Figure $2 \mathrm{C}$, the inhibition of actin microfilament assembly by cytochalasin B significantly decreased the endocytotic response of MDCK cells (34.2\% of control; $\mathrm{N}=8$; $\mathrm{P}<0.001$ ). Similarly, colchicine, a microtubule formation inhibitor, significantly reduced $\mathrm{CaOx}$ uptake by tubular cells $(46.1 \%$ of control; $\mathrm{N}=$ $8 ; \mathrm{P}<0.001)$. The control absolute score for both groups was $1.17 \pm 0.05(\mathrm{~N}=6)$.

The activation or the inhibition of ATPsensitive potassium channels by cromakalim and glibenclamide, respectively, did not alter significantly $\mathrm{CaOx}$ endocytosis $(\mathrm{N}=6$; $\mathrm{P}$ $=\mathrm{ns})$. Similarly, the tetraethylammonium-
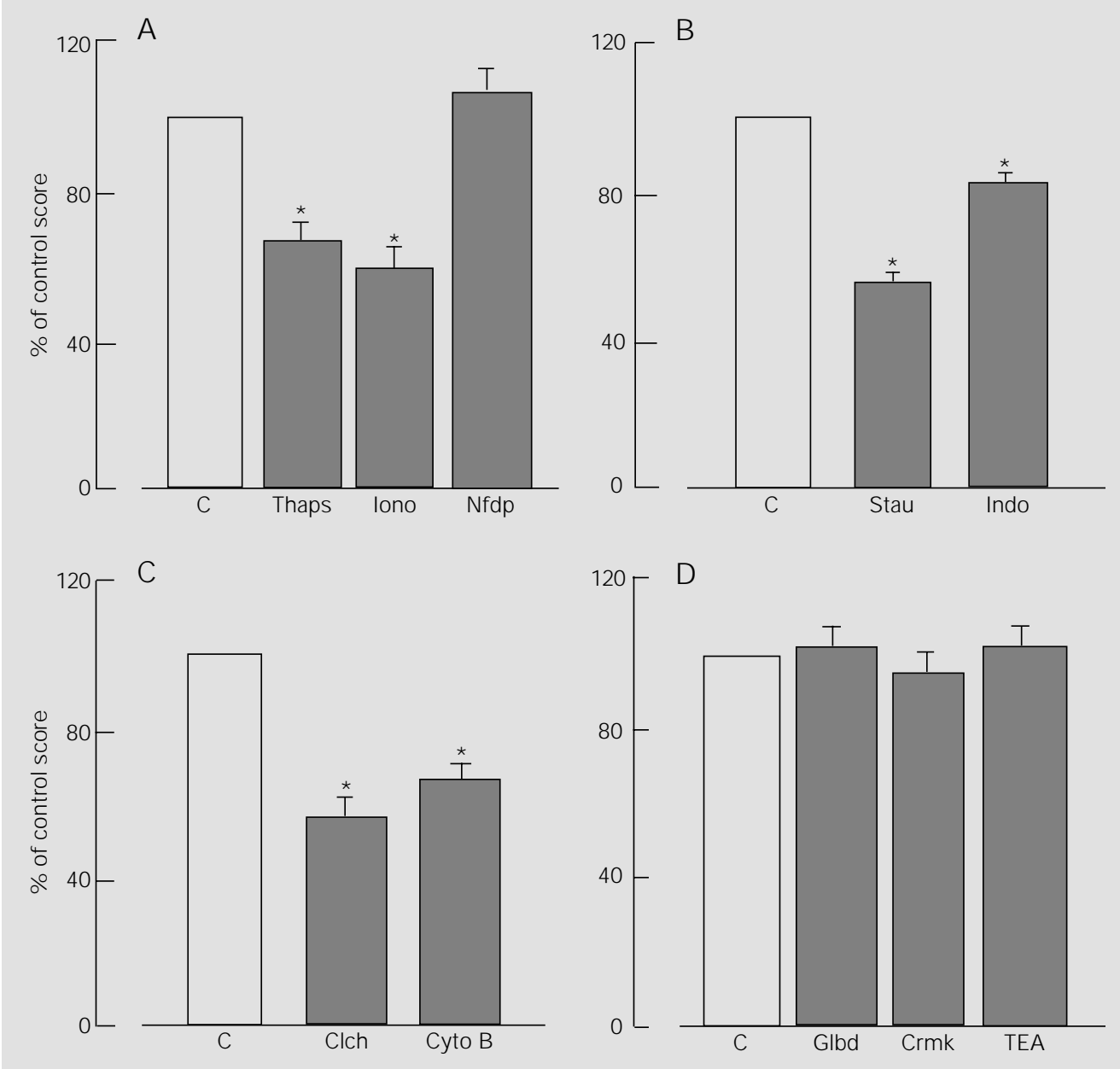

Figure 2 - Effect of different drugs on $\mathrm{CaO}$ x crystal endocytosis $(200 \mu \mathrm{g} / \mathrm{ml}, 6 \mathrm{~h}$ exposure time) by MDCK cells. Data are reported as percentage of control mean endocytosis scores. The columns represent the mean and the bars the SEM of at least 6 experiments. A, Thapsigargin (Thaps, $1 \mu \mathrm{M}$ ), ionomycin (Iono, $100 \mathrm{nM}$ ) and nifedipine (Nfdp, $10 \mathrm{nM}$ ). *P<0.005 compared to control (C) (Student t-test). B, Staurosporine (Stau, $10 \mathrm{nM}$ ) and indomethacin (Indo, $3 \mu \mathrm{M})$. $* \mathrm{P}<0.05$ compared to control (C) (Student t-test). C, Colchicine (Clch, $10 \mu \mathrm{M}$ ) and cytochalasin B (Cyto B, $10 \mu \mathrm{M}$ ). $* \mathrm{P}<0.001$ compared to control (C) (Student t-test). D, Glibenclamide (Glbd, $3 \mu \mathrm{M}$ ), cromakalim (Crmk, $1 \mu \mathrm{M})$ and tetraethylammonium (TEA, $1 \mathrm{mM}$ ). 
induced nonspecific blockade of potassium channels did not change the cytosolic $\mathrm{CaOx}$ content of MDCK cells exposed to relatively high crystal concentrations $(\mathrm{N}=6 ; \mathrm{P}=\mathrm{ns})$ (Figure 2D).

\section{Discussion}

Our technique for $\mathrm{CaOx}$ crystal production provided particles with dimensions and purity grade suitable for performing endocytosis assays. Moreover, the analysis of $\mathrm{CaOx}$ endocytosis kinetics confirmed previous data (15), showing that MDCK cells take up $\mathrm{CaOx}$ crystals in a time- and concentration-dependent manner, without detection of cell toxicity at the several concentrations tested, further validating our methods.

Alterations in $\left[\mathrm{Ca}^{2+}\right]_{i}$ play an important role in endocytosis and intracellular transport $(16,17)$. Enhancements in $\left[\mathrm{Ca}^{2+}\right]_{\mathrm{i}}$ from extra- or intracellular calcium sources induced by ionomycin and thapsigargin, respectively, significantly inhibited the MDCK cell $\mathrm{CaOx}$ internalization. On the other hand, in our study, the blockade of calcium influx via voltage-dependent channels by nifedipine did not promote relevant changes in crystal internalization. Indeed, a direct causative relationship between massive increments in intracellular calcium and endocytotic process inhibition has not been determined, as shown by $\mathrm{Wu}$ and Betz (18). The use of different calcium channel blockers and the measurement of $\left[\mathrm{Ca}^{2+}\right]_{\mathrm{i}}$ in MDCK cells after crystal internalization could help us solve this question.

Different investigators have reported considerable decreases of endocytosis in different models using protein kinase $\mathrm{C}$ inhibitors, with special emphasis on plasma membrane receptor recycling $(19,20)$. This phenomenon does not only apply to protein endocytosis and was well documented in MDCK cells when activators (such as derivatives of phorbol esters) and/or inhibitors of protein kinase $\mathrm{C}$ were employed $(21,22)$. This fact was evident also in the present study, with marked inhibition of $\mathrm{CaOx}$ internalization after exposure to staurosporine.

Another enzyme involved in the mechanisms of endocytosis is cyclo-oxygenase. Singhal et al. (23), for instance, have demonstrated the production of prostaglandin $\mathrm{E}_{2}$ by rat mesangial cells following colloidal gold particle internalization. In our model, indomethacin induced a slight inhibitory response, indicating a minor role for cyclooxygenase in $\mathrm{CaOx}$ endocytosis. Curiously, Lieske et al. (24) reported an inhibitory effect on $\mathrm{CaOx}$ endocytosis after administration of arachidonic acid (AA) and some of its metabolites ( $\mathrm{PGE}_{1}$ and $\mathrm{PGE}_{2}$ ) to MDCK cells. Thus, the involvement of AA cascade metabolites in these events deserves further investigation.

Cytochalasin B or colchicine also significantly reduced cellular $\mathrm{CaOx}$ crystal uptake. Several studies have demonstrated the participation of the cytoskeleton in endocytotic processes by inhibition of microtubules and/or actin microfilament assembly (2527). This especially occurs in epithelial cells where actin filaments and tubulin are relevant not only for cell polarity establishment and maintenance, but also for the intra- and transcellular process of particle distribution. The earlier intracellular events triggered by $\mathrm{CaOx}$ are related to the cytoskeleton. As already observed elsewhere, tubular cell crystal endocytosis is accompanied by F-actin concentration and cytokeratin net reorganization (28). Our data showed that alterations in the tubulin net are also present in this phenomenon, although data from Lieske et al. (28) pointed to an opposite direction. Furthermore, the inhibitory effect of cytochalasin B suggests that actin polymerization may be a more precocious event than $\mathrm{CaOx}$ crystal internalization, in contrast to the results of the above mentioned authors. However, although contradictory data exist, cytoskeleton mobilization is indispensable for the development of the $\mathrm{CaOx}$ internalization 
process by tubular epithelial cells.

Reductions in culture medium potassium concentration enhance $\mathrm{CaOx}$ internalization by tubular cells (1). In our study, potassium channel inhibitors (glibenclamide and tetraethylammonium) did not modify the magnitude of $\mathrm{CaOx}$ endocytosis by MDCK cells. The same occurred when the ATP-sensitive potassium channel activator, cromakalim, was employed, excluding the participation of some potassium channels in such phenomenon.

In conclusion, our study confirms and extends previous data showing that the process of $\mathrm{CaOx}$ uptake by tubular cells is inhibited by $\left[\mathrm{Ca}^{2+}\right]_{\mathrm{i}}$ increases, cytoskeleton assembly blockade, protein kinase $\mathrm{C}$ and, to a lesser extent, cyclo-oxygenase inhibition, but not by potassium channel blockade or activation. Thus, MDCK cells employ mechanisms for $\mathrm{CaOx}$ internalization quite similar to those observed in several types of endocytosis. These results may contribute to a better understanding of a phenomenon probably related to the pathophysiology of urolithiasis.

\section{Acknowledgments}

We thank Prof. Dr. Neusa P. da Silva, and Simone M. Camargo, Clara V. Razvickas and Otoniel Ribas for technical assistance. We also thank Prof. Dr. Renato A. Mortara for the support involving confocal microscopy observations.

\section{References}

1. Lieske J C \& Toback FG (1996). Interaction of urinary crystals with renal epithelial cells in the pathogenesis of nephrolithiasis. Seminars in Nephrology, 16: 458473.

2. Saxon A, Busch GJ , Merrill J P, Franco V \& Wilson RE (1974). Renal transplantation in primary hyperoxaluria. Archives of Internal Medicine, 133: 464-467.

3. Mandell I, Krauss E \& Millan J C (1980). Oxalate-induced acute renal failure in Crohn's disease. American J ournal of Medicine, 69: 628-632.

4. Khan SR, Finlayson B \& Hackett RL (1982). Experimental calcium oxalate nephrolithiasis in the rat. American J ournal of Pathology, 107: 59-69.

5. Khan SR, Cockrell CA, Finlayson B \& Hackett RL (1984). Crystal retention by injured urothelium of the rat urinary bladder. J ournal of Urology, 132: 153-157.

6. Khan SR, Shevock PN \& Hackett RL (1990). Membrane associated crystallization of calcium oxalate in vitro. Calcified Tissue International, 46: 116-120.

7. Lieske J C \& Toback FG (1993). Regulation of renal epithelial cell endocytosis of calcium oxalate monohydrate crystals. American J ournal of Physiology, 264: F800F807.

8. Verkoelen CF, Romijn J C, Cao LC, Boevé ER, De Bruijn WC \& Schröder FH (1996).
Crystal-cell interaction inhibition by polysaccharides. J ournal of Urology, 155: 749752.

9. Lieske J C, Leonard R \& Toback FG (1995). Adhesion of calcium oxalate monohydrate crystals to renal epithelial cells is inhibited by specific anions. American J ournal of Physiology, 268: F604-F612.

10. Parks J H \& Coe FL (1986). Urine citrate and calcium in calcium nephrolithiasis. Advances in Experimental Medicine and Biology, 208: 445-449.

11. Worcester EM, Nakagawa $Y$, Wabner CL, Kumar S \& Coe FL (1988). Crystal adsorption and growth slowing by nephrocalcin, albumin, and Tamm-Horsfall protein. American J ournal of Physiology, 255: F1197-F1205.

12. Hess B, Nakagawa $Y \&$ Coe FL (1989). Inhibition of calcium oxalate monohydrate crystal aggregation by urine proteins. American J ournal of Physiology, 257: F99F106.

13. Bergmeyer HV (1974). Methods in Enzymatic Analysis. Academic Press, New York, 574-589.

14. Lieske J C, Walsh-Reitz MM \& Toback FG (1992). Calcium oxalate monohydrate crystals are endocytosed by renal epithelial cells and induce proliferation. American J ournal of Physiology, 262: F622-F630.

15. Kohjimoto $Y$, Ebisuno $S$, Tamura $M \&$
Ohkawa T (1996). Interactions between calcium oxalate monohydrate crystals and Madin-Darby canine kidney cells: endocytosis and cell proliferation. Urological Research, 24: 193-199.

16. Ninomiya $Y$, Kishimoto $T$, Miyashita $Y \&$ Kasai H (1996). $\mathrm{Ca}^{2+}$-dependent exocytotic pathways in Chinese hamster ovary fibroblasts revealed by a caged-Ca ${ }^{2+} \mathrm{com}-$ pound. J ournal of Biological Chemistry, 271: 17751-17754.

17. Llorente A, Garred O, Holm PK, Eker P, J acobsen J, Van Deurs B \& Sandvig K (1996). Effect of calmodulin antagonists on endocytosis and intracellular transport of ricin in polarized MDCK cells. Experimental Cell Research, 227: 298-308.

18. Wu LG \& Betz WJ (1996). Nerve activity but not intracellular calcium determines the time course of endocytosis of the frog neuromuscular junction. Neuron, 17: 769-779.

19. Moraru II, Laky M, Stanescu T, Buzila L \& Popescu LM (1990). Protein kinase C controls Fc gamma receptor-mediated endocytosis in human neutrophils. FEBS Letters, 274: 93-95.

20. Fallon RJ \& Danaher M (1992). The effect of staurosporine, a protein kinase inhibitor, on asialoglycoprotein receptor endocytosis. Experimental Cell Research, 203: $420-426$ 
21. Holm PK, Eker $P$, Sandvig K \& Van Deurs B (1995). Phorbol myristate acetate selectively stimulates apical endocytosis via protein kinase $C$ in polarized MDCK cells. Experimental Cell Research, 271: 157168.

22. Cardone MH, Smith BL, Song W, MochlyRosen D \& Mostov KE (1994). Phorbol myristate acetate-mediated stimulation of transcytosis and apical recycling in MDCK cells. J ournal of Cell Biology, 124: 717727.

23. Singhal PC, Ding GH, De Candido S, Franki N, Hays RM \& Schlondorff D (1987). Endocytosis by cultured mesangial cells and associated changes in prostaglandin $E_{2}$ synthesis. American J ournal of Physiology, 252: F627-F634.

24. Lieske J C, Norris R \& Toback FG (1997). Calcium oxalate monohydrate crystal adhesion to renal epithelial cells is modulated by arachidonic acid and its metabolites. J oumal of the American Society of Nephrology, 8: 564A (Abstract).

25. Ramm GA, Powell LW \& Halliday J W (1994). Pathways of intracellular trafficking and release of ferritin by the liver in vivo: the effect of chloroquine and cytochalasin D. Hepatology, 19: 504-513.

26. Lamaze C, Fujimoto LM, Yin HL \& Schmid SL (1997). The actin cytoskeleton is required for receptor-mediated endocytosis in mammalian cells. J ournal of Biological Chemistry, 272: 20332-20335.

27. Gottlieb TA, Ivanov IE, Adesnik M \& Sabatini DD (1993). Actin microfilaments play a critical role in endocytosis at the apical but not the baso-lateral surface of polarized epithelial cells. J ournal of Cell Biology, 120: 695-710.

28. Lieske J C, Swift H, Martin T, Patterson B \& Toback FG (1994). Renal epithelial cells rapidly bind and internalize calcium oxalate monohydrate crystals. Proceedings of the National Academy of Sciences, USA, 91: 6987-6991. 